\title{
Nicolas Pasquier, Le Gentilhomme
}

\section{Antonella Arrigoni}

\section{(2) OpenEdition}

\section{Journals}

\section{Edizione digitale}

URL: https://journals.openedition.org/studifrancesi/39196

DOI: 10.4000/studifrancesi.39196

ISSN: 2421-5856

\section{Editore}

Rosenberg \& Sellier

\section{Edizione cartacea}

Data di pubblicazione: 1 décembre 2004

Paginazione: 357

ISSN: 0039-2944

\section{Notizia bibliografica digitale}

Antonella Arrigoni, «Nicolas Pasquier, Le Gentilhomme», Studi Francesi [Online], 143 (XLVIII | II) | 2004

online dal 30 novembre 2015, consultato il 19 mai 2021. URL: http://journals.openedition.org/

studifrancesi/39196 ; DOI: https://doi.org/10.4000/studifrancesi.39196

Questo documento è stato generato automaticamente il 19 mai 2021.

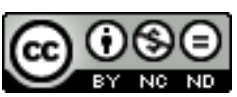

Studi Francesi è distribuita con Licenza Creative Commons Attribuzione - Non commerciale - Non opere derivate 4.0 Internazionale. 


\title{
Nicolas Pasquier, Le Gentilhomme
}

\author{
Antonella Arrigoni
}

\section{NOTIZIA}

NICOLAS PASQUIER, Le Gentilhomme, édition critique par Denise CARABIN, Paris, Champion, 2003, pp. 383.

1 Opera breve, ma ben articolata. Le Gentilhomme propone un percorso educativo per i giovani nobili dove nulla viene tralasciato; sono infatti presi in esame molteplici aspetti che concorrono all'educazione culturale e morale - le belle maniere, la vita sociale e giuridica, gli studi umanistici, il mestiere delle armi. La ricca parte introduttiva, suddivisa in diversi capitoli dedicati alla formazione dell'autore, alla genesi e alla composizione del testo, presenta l'opera e sottolinea l'ampia cultura di Pasquier, le cui letture vanno dai classici antichi agli autori moderni francesi e stranieri. La seconda parte dell'introduzione è incentrata sull'analisi degli ideali etici e politici professati da Pasquier e posti alla base della formazione morale ed intellettuale del giovane nobile. Completano l'opera una nota analitica relativa ai criteri di edizione adottati, un glossario e una ricca bibliografia. 